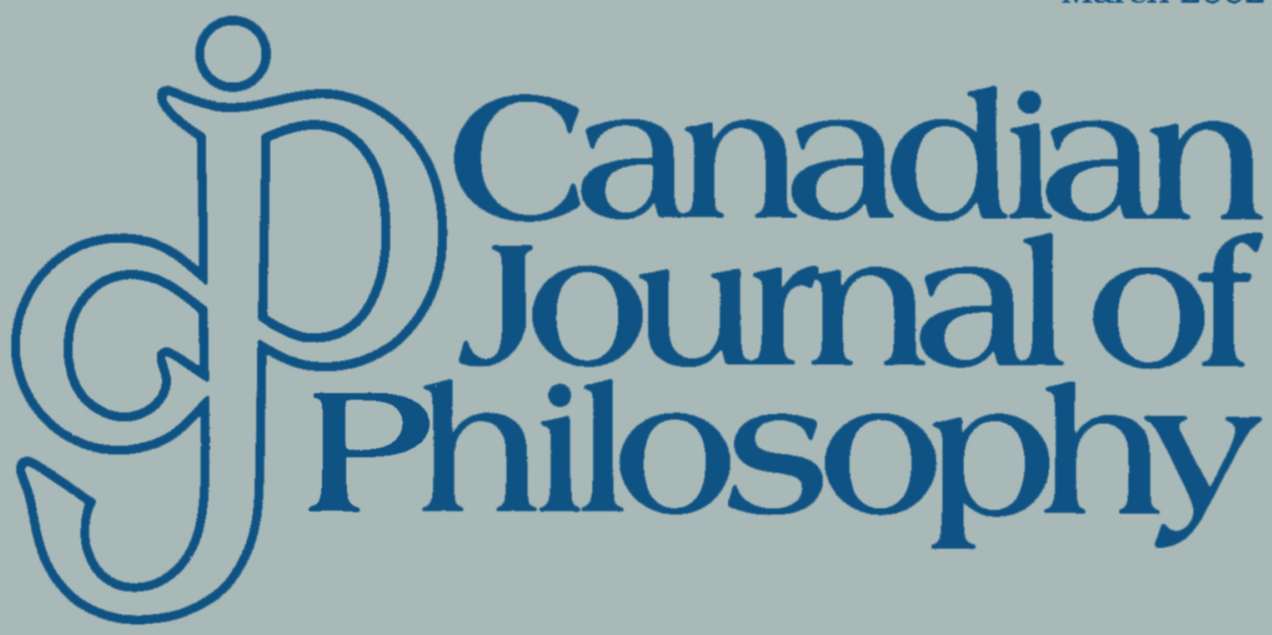

CONSCIOUSNESS, EXPERIENCE, AND JUSTIFICATION

THE FALLACY OF PHILANTHROPY

Paul Gomberg

PARFIT ON PAINS, PLEASURES, AND THE

TIME OF THEIR OCCURRENCE

Dan Moller

FALLIBILISM AND KNOWING THAT ONE

IS NOT DREAMING

Stephen Hetherington

WELFARE AND OUTCOME

Robert Shaver

CRITICAL NOTICE OF MARGARET MORRISON

UNIFYING SCIENTIFIC THEORIES: PHYSICAL

CONCEPTS AND MATHEMATICAL STRUCTURES

Andrew Wayne 


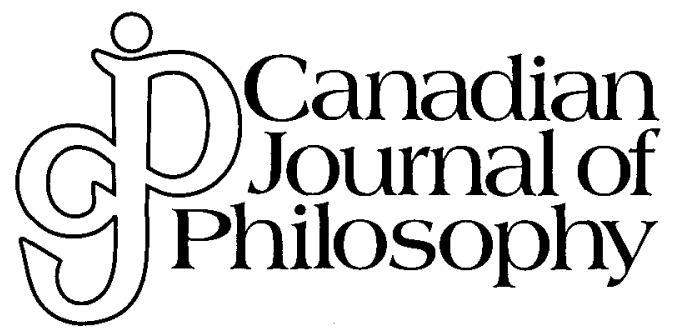




\section{Donadian
Journal of
Philosophy}

VOLUME 32

2002

Editors

Administrative Editor MICHAEL STINGL

Executive Secretary
University of Lethbridge

SAMANTHA BRENNAN

University of Western Ontario

STEVEN DAVIS

Simon Fraser University

MARC ERESHEFSKY

University of Calgary

BRUCE HUNTER

University of Alberta

THOMAS HURKA

University of Calgary

THOMAS M. LENNON

University of Western Ontario

CHERYL MISAK

University of Toronto

ROBERT J. STAINTON

Carleton University

DANIEL WEINSTOCK

Université de Montréal

ANNE WILLIAMS 
TABLE OF CONTENTS
CONSCIOUSNESS, EXPERIENCE,

AND JUSTIFICATION

Harold Langsam

THE FALLACY
Paul Gomberg

PARFIT ON PAINS, PLEASURES, AND THE

TIME OF THEIR OCCURRENCE

Dan Moller

67

FALLIBILISM AND KNOWING THAT ONE

IS NOT DREAMING

Stephen Hetherington

WELFARE AND OUTCOME

Robert Shaver

CRITICAL NOTICE OF MARGARET MORRISON UNIFYING SCIENTIFIC THEORIES: PHYSICAL CONCEPTS AND MATHEMATICAL STRUCTURES Andrew Wayne

Notes on Contributors/Sur les Collaborateurs

List of Referees

Information for Authors/Avis aux Auteurs

Subscription Information/Abonnements

Other Business Information/

Services administratifs—détails supplementaires 


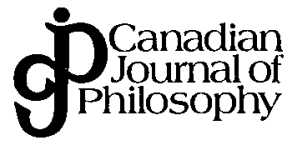

\section{FROM THE EDITORIAL BOARD}

The Canadian Journal of Philosophy is pleased to announce that, beginning this year, it will award an annual Canadian Journal of Philosophy Prize of $\$ 1000$ to the best paper accepted by the editors in a given year. Papers submitted in 2001 are eligible for the 2002 prize if they are accepted in 2002; papers solicited and not voted on by the editors are not eligible. The winner of this year's prize will be announced early in 2003.

Evan Thompson has left the journal's editorial board to pursue other projects, though he will continue to edit the 2003 Supplementary Volume on Phenomenology and Philosophy of Mind. The journal thanks Evan for his contributions and welcomes his replacement on the board, Robert J. Stainton.

\author{
Thomas Hurka \\ Editorial Board Coordinator
}

